\title{
Fallopian Tube Cancer pM1 TNM Finding v7
}

National Cancer Institute

\section{Source}

National Cancer Institute. Fallopian Tube Cancer pM1 TNM Finding v7. NCI Thesaurus.

Code $C 89687$.

Fallopian tube cancer with distant metastasis (excluding metastasis within the peritoneal cavity). (from AJCC 7th Ed.) 